\title{
Ketamine exhibits anti-gastric cancer activity via induction of apoptosis and attenuation of PI3K/Akt/mTOR
}

\author{
Shiling Zhao ${ }^{1}$, Lin Shao ${ }^{1}$, Yingwei Wang ${ }^{1}$, Qingtao Meng 2 , Jinning Yü
}

1Department of Anesthesiology, The Third People's Hospital of Dalian, Dalian, China
'Department of Spinal, Department of Anesthesiology, The Third People's Hospital
of Dalian, Dalian, China
3Department of General Surgery, The Third People's Hospital of Dalian, Dalian, China

Submitted: 13 November 2018

Accepted: 27 January 2019

Arch Med Sci 2020; 16 (5): 1140-1149

DOI: https://doi.org/10.5114/aoms.2019.85146

Copyright (c) 2019 Termedia \& Banach

\section{Abstract}

Introduction: Gastric cancer (GC) is the most widespread type of cancer after lung and liver cancer in men and after breast cancer in women. Thus, the present study was intended to evaluate the effect of ketamine (KET) on gastric cancer cells.

Material and methods: The effect of KET was analyzed in vitro by the MTT assay against human gastric cancer cell lines BGC-823, MKN-45 and MKN-28. The effect KET on apoptosis, cell migration and cell cycle arrest was also quantified. Western blot analysis was performed to estimate the effect of KET on apoptosis mediators and PI3K/AKT/mTOR pathway mediators. A mouse xenograft assay was also conducted to further confirm the anticancer activity.

Results: KET causes reduction of cellular viability of BGC-823, MKN-45 and $M K N-28$, with a more significant effect against BGC-823 cells. The KET treatment showed a dose-dependent increase in apoptotic cells among BGC-823 cells. KET causes a significant dose-dependent decline in migration of treated cells. It causes induction of apoptosis mediated via the mitochondrial pathway, where it causes a decline in $\mathrm{Bcl} 2$ and mitochondrial cytochrome $\mathrm{C}$ level together with increase in expression of Bax, cytosolic cytochrome $\mathrm{c}$ and cytosolic apoptotic protease activating factor-1 (Apaf-1). The level of p-PI3K, p-mTOR, p-GSK3 $\beta$ and p-AKT was found to be downregulated in a dose-dependent manner in KET-treated cells. In a mouse xenograft model, KET causes a reduction in relative tumour volume and tumour weight.

Conclusions: Our results suggest that ketamine has the ability to inhibit progression of gastric cancer via induction of apoptosis and attenuation of $\mathrm{PI} 3 \mathrm{~K} / \mathrm{Akt} / \mathrm{mTOR}$.

Key words: ketamine, gastric cancer, viability, apoptosis, PI3K, Akt, mTOR.

\section{Introduction}

The incidence of morbidity and mortality has made cancer a major threat to human life in both developed and resource-poor countries [1]. Despite excellent diagnostic and therapeutic options against cancer, a definite cure for this dreadful disease is still not available [2]. The effective management of cancer is greatly problematic due to multiple etiologic factors, relapse and severe side-effects of anticancer agents [3]. In China, gastric cancer (GC) is the most widespread type of cancer after lung and liver cancer in men and after breast cancer in women. The

\author{
Corresponding author: \\ JinningYu \\ Department \\ of General Surgery \\ The Third People's \\ Hospital of Dalian \\ 116031 Dalian, China \\ Phone/fax: \\ +86041186525346 \\ E-mail: AsbillLekicimiv@ \\ yahoo.com
}


severity of disease could be easily understood by the fact that approximately half of the world's GC cases and deaths occur in China [4-6]. The poor prognosis and diagnosis are the major hurdles for the treatment of GC, because the patients are often diagnosed at an advanced stage of disease. Regardless of advances of novel and efficient chemotherapeutic agents, the survival rate for patients is very poor and in the most advanced stage is less than 1 year [7]. Accumulating evidence suggests that different signalling pathways are implicated in the development of GC and induction of resistance against drugs [8]. Therefore, there is an urgent need to discover a novel agent which can selectively inhibit GC by attenuating the key signalling pathway involved in progression.

The genome-wide profiling of genetic aberrations from GC patients suggested the involvement of phosphatidylinositol-3-kinase (PI3K)/Akt (protein kinase $\mathrm{B}) / \mathrm{mammalian}$ (or mechanistic) target of rapamycin (mTOR) signalling pathway in anti-apoptosis and pro-survival. It manages cellular transcription/translation, proliferation and survival of GC [9-12]. Therefore, inhibition of the $\mathrm{PI} 3 \mathrm{~K} / \mathrm{AKT} / \mathrm{mTOR}$ signalling pathway is deemed as a striking opportunity for the development of novel anticancer agents and numerous agents have entered phase I, II or III clinical trials.

Ketamine (KET) is an intravenous anaesthetic, which acts in a non-competitive way to antagonise the N-methyl-D-aspartate (NMDA) receptor, for the treatment of postoperative, chronic cancer pain and neuropathic pain, respectively [13, 14]. Accumulating evidence supports the anticancer activity of ketamine against various cancers, for instance, pancreatic cancer [15], lung adenocarcinoma [16] and neuroblastoma [17]. Nevertheless, the effect of ketamine on GC remains unknown. Thus the current study was undertaken to examine the anti-gastric cancer potential of ketamine. The study also determined whether ketamine-induced apoptosis is mediated via an effect on the $\mathrm{PI} 3 \mathrm{~K} / \mathrm{AKT} / \mathrm{mTOR}$ signalling pathway.

\section{Material and methods}

\section{Reagents and materials}

Ketamine was obtained from Sigma Aldrich (USA). The antibodies against Bax, Bcl-2, cleaved caspase-3, cytochrome c, PI3K, p-PI3K, Akt, p-Akt, mTOR and $p$-mTOR and $\beta$-actin were obtained from Santa Cruz Biotechnology (USA). The Trizol reagent kit was procured from Invitrogen (USA). The MTT assay kit was obtained from Sigma-Aldrich (USA). All other primary antibodies, as well as anti-rabbit and anti-mouse secondary horseradish-peroxidase antibodies, were purchased from Abcam (USA) [18].

\section{Cell culture}

The human gastric cancer cell lines BGC-823, MKN-45 and MKN-28 were purchased from Shanghai Institutes for Biological Sciences, Chinese Academy of Science (Shanghai, China). The cells were cultured in DMEM medium supplemented with $10 \%$ FBS, $1 \%$ penicillin, and $1 \%$ streptomycin in a humidified atmosphere of $95 \%$ air and $5 \% \mathrm{CO}_{2}$ at $37^{\circ} \mathrm{C}$.

\section{Cell viability assay}

The cellular viability was evaluated by MTT assay. Briefly, the cells (BGC-823, MKN-45 and MKN-28) were seeded in 96-well plates and treated with KET for $48 \mathrm{~h}$ according to the manufacturer's protocol. The absorbance was measured at $490 \mathrm{~nm}$ test wavelength and $570 \mathrm{~nm}$ reference wavelength with an enzyme-linked immunosorbent assay multi-well spectrophotometer (MDC, Sunnyrale, CA).

\section{Annexin $\mathrm{V}$ and propidium iodide $(\mathrm{PI})$ staining}

The effect of KET on apoptosis was evaluated by an annexin V/PI detection assay. Briefly, After $48 \mathrm{~h}$ of KET treatment, the SGC-823 cells were analyzed by flow cytometry (FACScan, Becton Dickinson, USA) according to the manufacturer's instructions (annexin V-FITC apoptosis kit, BD Biosciences, USA). Data were further analyzed with the CellQuest software (Becton Dickinson). The experiments were performed in serum-free medium in triplicate.

\section{Fluorescent microscopy}

The SGC-823 cells were washed with PBS and fixed in cold methanol and acetic acid ( $3: 1, \mathrm{v} / \mathrm{v})$ before being stained with Hoechst 33342 after treatment with KET for $48 \mathrm{~h}$. The stained cells were visualized with a fluorescence microscope (400×, Nikon, Japan).

\section{Transwell migration assay}

The effect of KET on the migration of BGC823 cells was analysed using Transwell chambers with 8-mm porous membrane (Corning, Corning, NY, USA). For the migration of human gastric cancer cells (BGC-823) in monoculture, $1 \times 10^{5}$ cells/ well were plated in the upper chambers of Transwell plates with 8- $\mu \mathrm{m}$ pore polycarbonate membrane inserts in a medium without fetal bovine serum (FBS). A medium with FBS was plated in the lower chambers. After treatment or no treatment with dimethyl sulfoxide (DMSO) and with the indicated treatment for 16-24 h, the cells that had migrated to the bottom were fixed and 
stained using $1 \%$ toluidine blue. The numbers of cells were averaged after six randomly selected fields were counted. Each sample was assayed in triplicate, and each experiment was repeated at least twice and the number of migratory cells was counted by fluorescence microscopy (magnification, 100x).

\section{Western blot analysis}

The cells were washed with PBS and suspended in extraction buffer to isolate the whole cell extract. Moreover, $50 \mu \mathrm{g}$ of boiling sample buffer was added to the whole cell lysate and the mixture was boiled for $10 \mathrm{~min}$ at $100^{\circ} \mathrm{C}$. The protein extract was separated by $12 \%$ SDS-PAGE and transferred onto PVDF membrane (Millipore, Billerica, MA, USA) and blocked for $1 \mathrm{~h}$ at room temperature in blocking buffer. The blocked protein was then probed with primary antibodies (1 : 1,000 in $1 \%$ BSA/TBS-T) overnight at $4^{\circ} \mathrm{C}$, such as, p-AKT (Ser-473), p-mTOR (Ser-2448), p-GSK3 $\beta$ (Ser-9), and p-PI3K (Tyr-458). The membranes were then washed twice for 15 min each in TBS-T and incubated with HRP-conjugated goat anti-mouse or -rabbit antibodies (1:10,000 in $1 \%$ BSA/TBS-T). Cytosolic and mitochondrial fractions were extracted by centrifugation, which resulted in the supernatant (containing cytosol and microsomal fraction). It was precipitated in cold $100 \%$ acetone at $-20^{\circ} \mathrm{C}$ for at least $1 \mathrm{~h}$ followed by centrifugation at $12,000 \mathrm{~g}$ for $5 \mathrm{~min}$ and the pellet was then resuspended in 100-300 $\mu$ l of STM buffer and labelled as the "cytosolic fraction". The other pellet from the same supernatant was again resuspended in 100-200 $\mu$ l of STM buffer and centrifuged at $11,000 \mathrm{~g}$ for $10 \mathrm{~min}$. Once centrifuged, the supernatant was discarded, the mitochondrial pellet was resuspended in 50-100 $\mu$ l of SOL buffer (comprising: $50 \mathrm{mM}$ Tris $\mathrm{HCl} \mathrm{pH} 6.8,1 \mathrm{mM}$ EDTA, $0.5 \%$ Triton-X-100, protease and phosphatase inhibitors) by sonication on ice at a high setting for 5-10s with 30-second pauses and labelled as the "mitochondrial fraction".

\section{Xenograft assay}

The female nude mice (BALB/c nu/nu, age: 46 weeks) were obtained from the institutional animal house and kept in a sterile environment in an alternate 12 -h light and dark cycle at $24^{\circ} \mathrm{C}$ until the initiation of the experiment. The experiment was carried out according to the Guide for the Care and Use of Laboratory Animals and was approved by the Animal Ethics Committee of the institute. For induction of tumour, SGC-823 cells $\left(1 \times 10^{5}\right.$ cells/mouse) were administered into the right flank of each mouse. After reaching the optimal tumour size $\left(110-130 \mathrm{~mm}^{3}\right)$ after 10 days, the nude mice were randomly divided into three groups $(n=5)$ :

- Control: Normal saline,

- Second group: KET (5 mg/kg),

- Third group: KET (10 mg/kg).

The mentioned concentration of KET was injected into mice intraperitoneally (once a day for 3 weeks). Tumour length and width were measured using a caliper and the tumour volume was calculated using the following formula: tumour volume $=$ length $\times$ width $\times 0.5$ width .

\section{Results}

\section{Growth inhibitory effect of KET on BGC-823, MKN-45 and MKN-28 gastric cancer cell lines}

The initial part of the study was performed to determine the effect of KET in diverse concentrations on the viability of MKN-45, MKN-28 and BGC-823 gastric cancer cell lines. We used three different concentrations of KET, i.e., 2, 5 and $10 \mu \mathrm{g} / \mathrm{ml}$, and the results are summarized in Figure 1 . Our results suggest that KET showed a de crease in viability of cells in a concentration- and time-dependent manner. The KET showed a more pronounced effect on BGC-823 (Figure $1 \mathrm{C}$ ) than MKN-45 (Figure $1 \mathrm{~A}$ ) and MKN-28 (Figure $1 \mathrm{~B}$ ) cells. Particularly against BGC-823, KET showed $59 \%$ inhibition at the highest test dose of $10 \mu \mathrm{g} /$ $\mathrm{ml}$ in $24 \mathrm{~h}$ and as the time increased to $72 \mathrm{~h}$, it showed $93 \%$ inhibition. The same concentration showed $38 \%$ and $48 \%$ inhibition of MKN-45 and MKN-28 cells at $24 \mathrm{~h}$, respectively.

\section{Ketamine induces apoptosis in BGC-823 cells}

Encouraged by the excellent inhibitory activity of KET against BGC-823, we intended to investigate the detailed mechanism behind the anticancer activity of KET. Thus, in the next part we are in terested to know whether the observed inhibitory effect of KET on BGC-823 cells was linked with the induction of apoptosis. We performed flow cytometry analysis of annexin $\mathrm{V}$ and propidium iodide (PI) staining to assess the percentage of apoptotic cells after $24 \mathrm{~h}$ treatment of KET in BGC-823 cells, and the results are presented in Figures $2 \mathrm{~A}$ and $\mathrm{B}$. The results showed that KET caused a dose-dependent increase in late apoptotic cells in the treated group. The most prominent activity was reported in the case of the $10 \mu \mathrm{g} / \mathrm{ml}$ treated group. Fluorescence microscopy was also conducted on cells after treatment with $\mathrm{KET}$, and the results are presented in Figure $2 \mathrm{C}$. It was found that chromatin was condensed together with fragmentation of nuclear material and presence of apoptotic bodies in treated cells. The above observation confirmed 
A

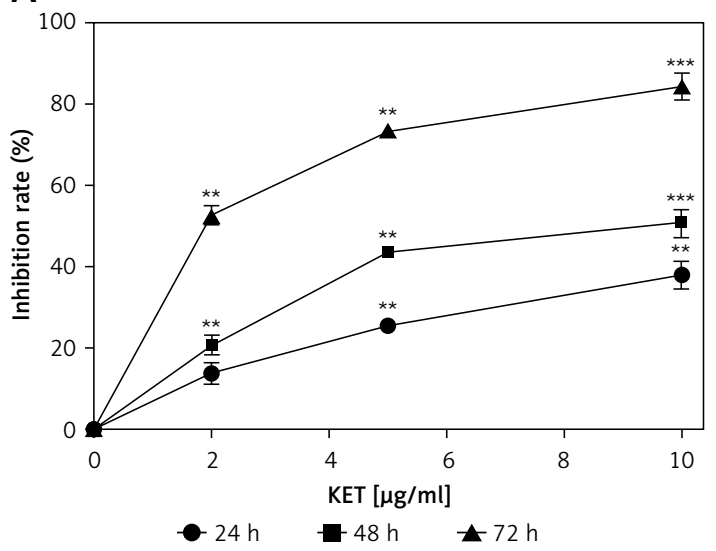

C

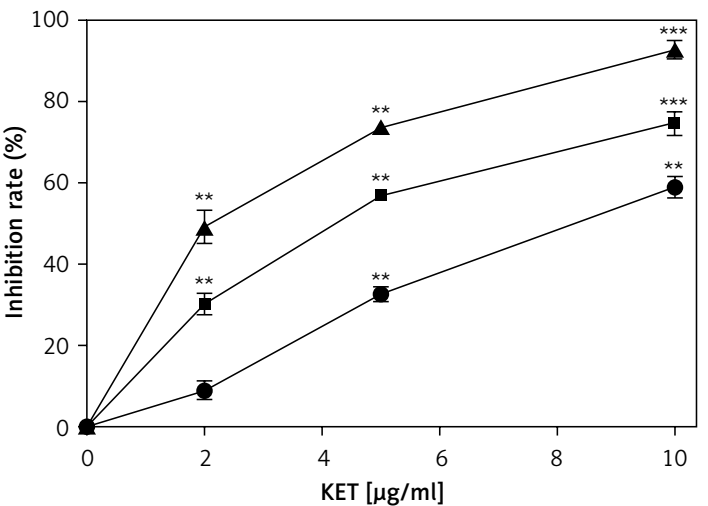

that KET causes significant induction of apoptosis as evidenced by characteristic morphological changes in treated BGC-823 cells in a concentration-dependant manner.

\section{Migration of BGC-823 cells inhibited by KET}

This study was conducted to assess the effect KET on the migration of BGC-823 cells after $24 \mathrm{~h}$ of treatment. The results showed that KET causes a significant dose-dependent decline in migration of treated cell, Figures $3 \mathrm{~A}$ and B. More significant inhibition was observed in the case of the $10 \mu \mathrm{g} / \mathrm{ml}$ treated group.

\section{Effect of KET on apoptosis-associated proteins in BGC-823 cells}

The level of apoptosis-related proteins was evaluated in BGC-823 cells after treatment with KET by western blot analysis. As shown in Figure 4, the level of $\mathrm{Bcl} 2$ was significantly downregulated in the KET treated group with significant upregulation of Bax expression in a dose-dependent manner. The activity of caspase- 3 was also enhanced after treatment with KET, Figure $4 \mathrm{D}$. The next part of the study aimed to assess the effect of KET on the release of cytochrome c; thus we evaluated the expression of cytosolic and mitochondrial cyto-

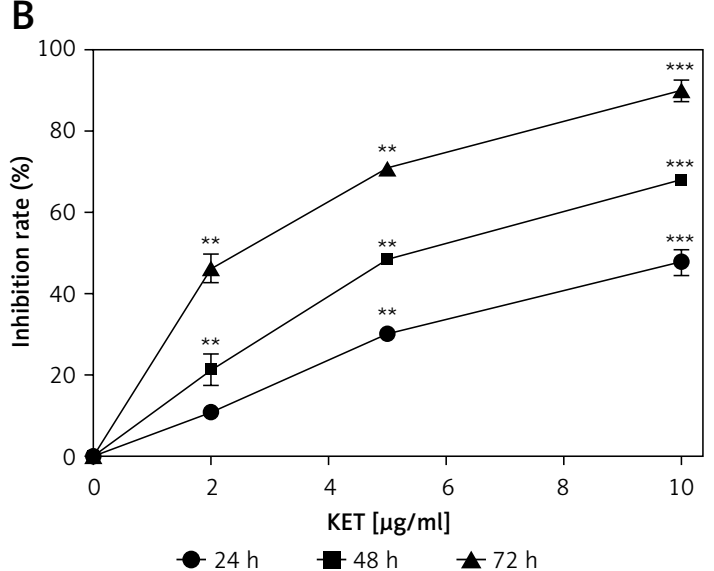

Figure 1. Effect of KET on cell viability assay, were: BGC-823 (A), MKN-45 and MKN-28 (B) and BGC823 (C)

Results represent means $\pm S D$ of three independent experiments. ${ }^{* *} P<0.01 ;{ }^{* * *} p<0.001$ vs. control group.

chrome c. As presented in blot analysis (Figure $4 \mathrm{~A}$ ) and representative histograms (Figures $4 \mathrm{E}-\mathrm{G}$ ), the expression of mitochondrial cytochrome $\mathrm{c}$ decreased with the increase in cytosolic cytochrome c together with the increase in cytosolic apoptotic protease activating factor-1 (Apaf-1). These results suggest the involvement of the mitochondrial pathway in KET-induced apoptosis.

\section{KET targets PI3K/AKT/mTOR pathway}

Inhibition of the PI3K/AKT/mTOR signalling cascade is an attractive target for the treatment of gastric cancer. Thus, this part of the study aimed to determine the effect of KET on expression of the proteins involved in this pathway. As presented in Figure 5, the results demonstrated that KET-treated cells cause downregulation of $\mathrm{p}$-PI3K, p-mTOR, $p$-GSK3 $\beta$ and $p$-AKT in a dose-dependent manner.

\section{Effect of KET xenograft assay}

Encouraged by the excellent in-vitro activity of KET in gastric cancer cells, we next evaluated the inhibitory potential of KET in an in-vivo mouse SGC-823 xenograft model. As presented in Figure 6 , it was found that KET showed a reduction in the relative tumour volume with the most signif- 
A
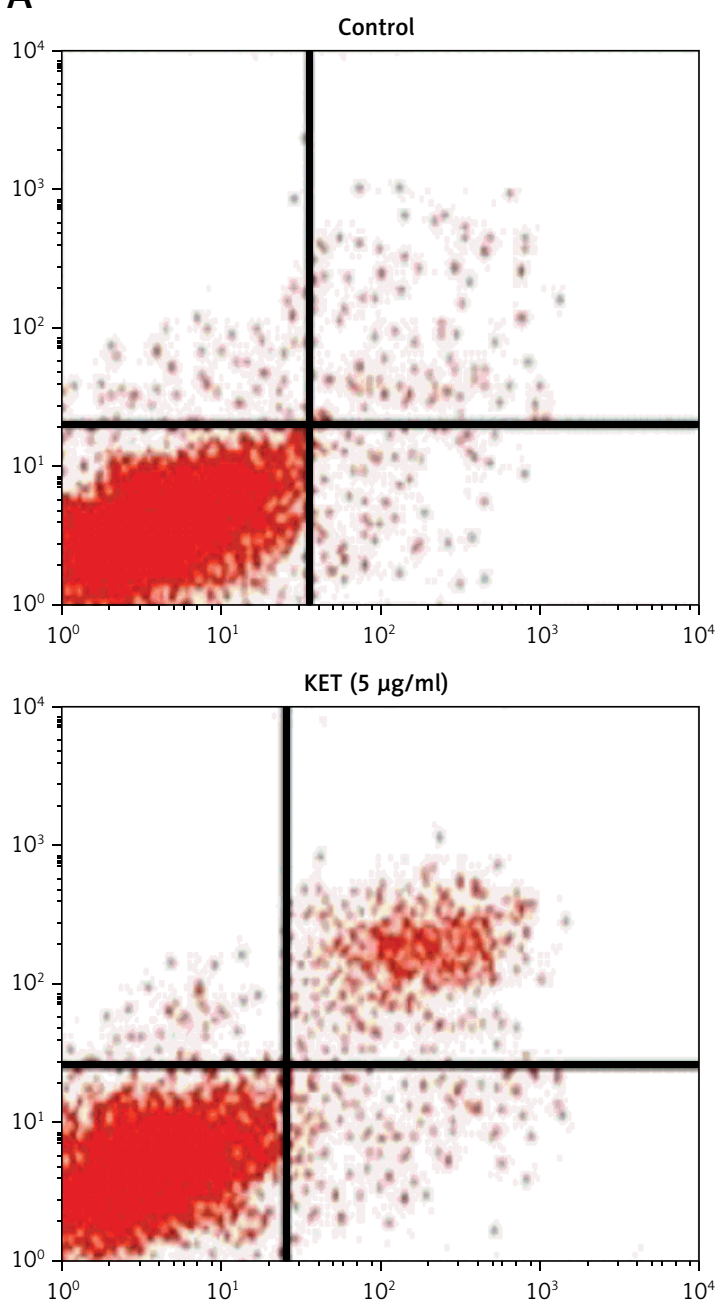
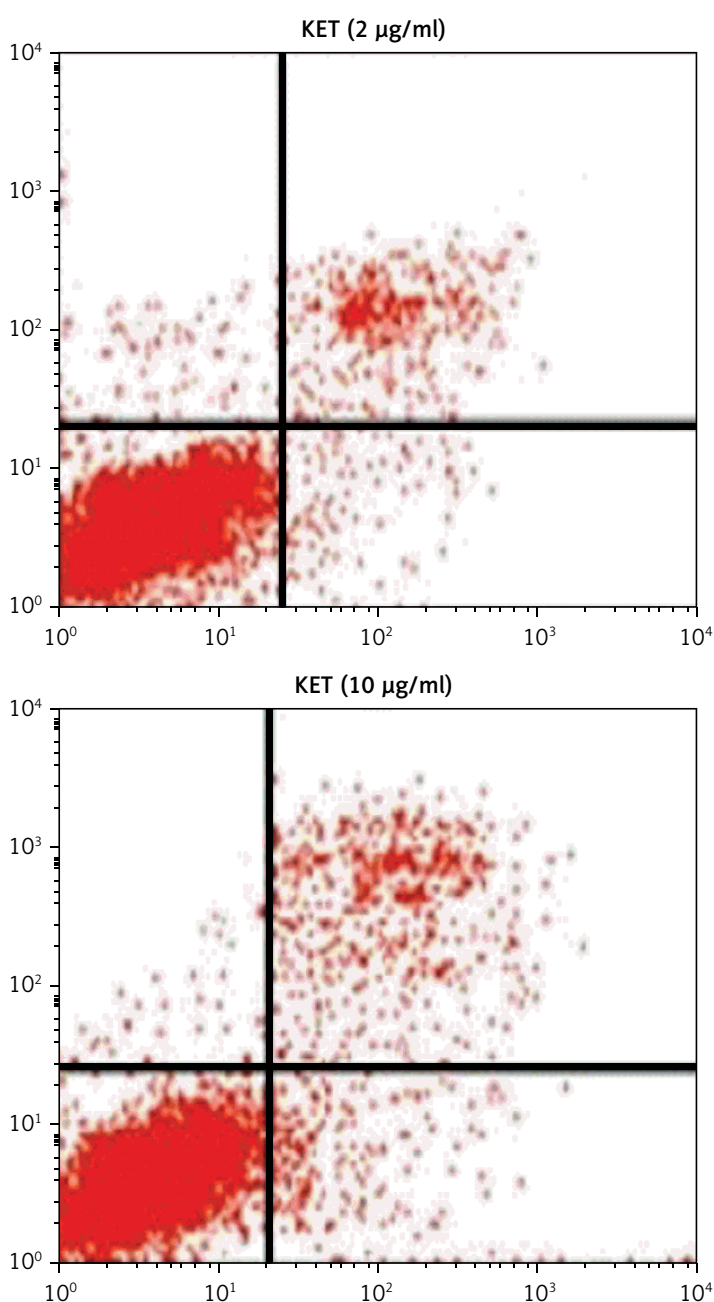

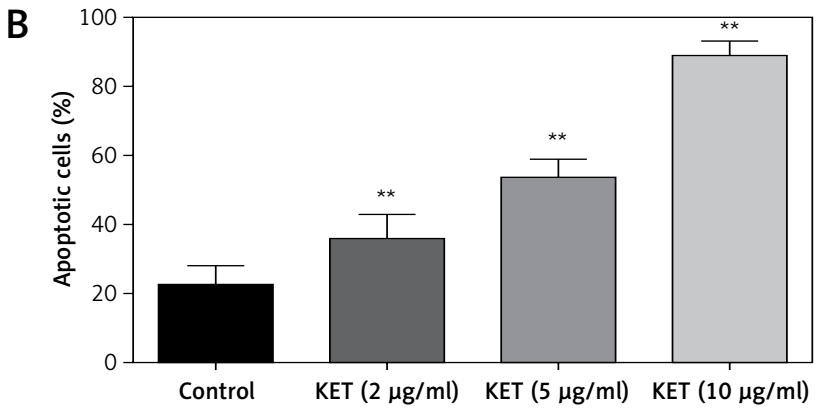

C
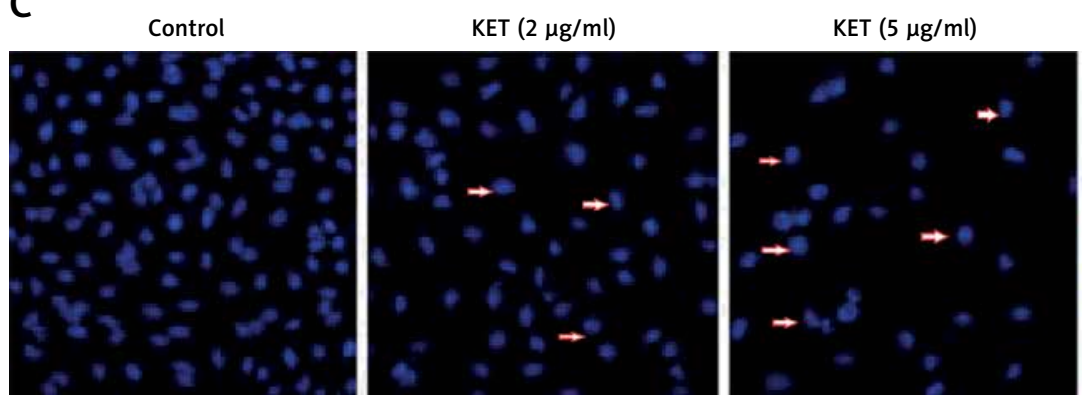

KET $(10 \mu \mathrm{g} / \mathrm{ml})$

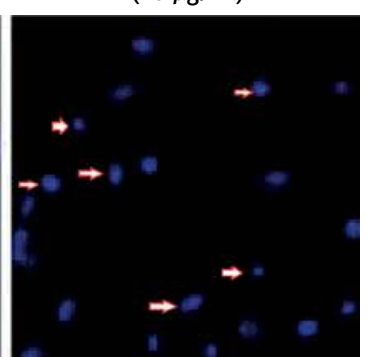

Figure 2. Effect of KET on apoptosis of BGC-823 cells. A - Pl-annexin V-FITC binding assay using 2, 5, and $10 \mu \mathrm{g} / \mathrm{ml}$ of KET on BGC-823 cells, $\mathbf{B}$ - column representing the percentage of apoptotic cells, $\mathbf{C}$ - effect of KET on apoptosis as determined by fluorescence micrographs of BGC-823 cells

Results represent means $\pm S D$ of three independent experiments. ${ }^{* *} P<0.01 \mathrm{vs}$. control group. 
A
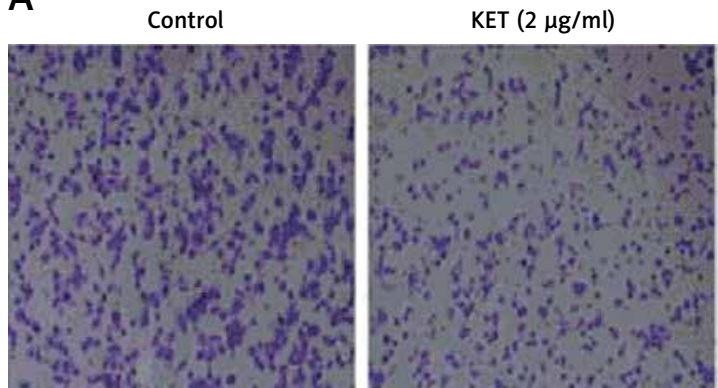

B

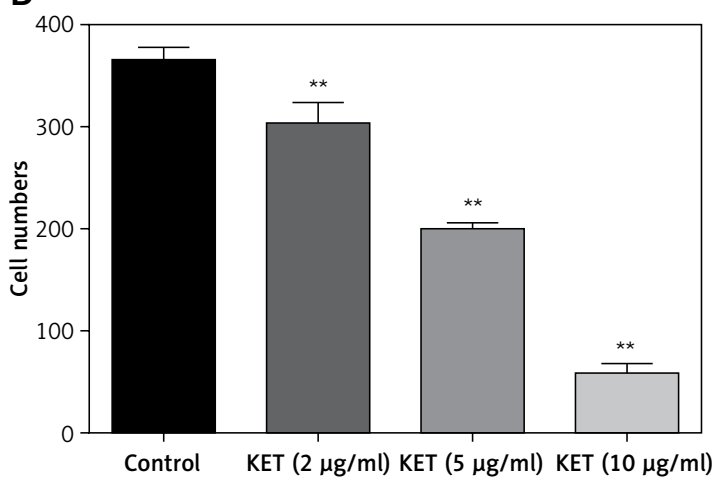

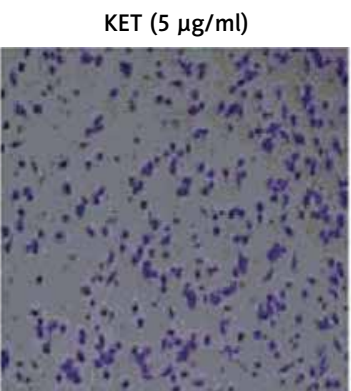

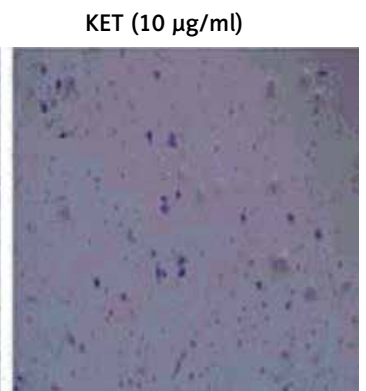

Figure 3. Effect of KET in Transwell migration of BGC-823 cells. A - KET-treated BGC-823 cells were loaded into the upper migration chamber, $\mathbf{B}-$ representative bar graph of migratory BGC-823 cells

Results represent means $\pm S D$ of three independent experiments. ${ }^{* *} P<0.01$ vs. control group. icant activity in the $10 \mathrm{mg} / \mathrm{kg}$ dose as compared to the control. Moreover, the $5 \mathrm{mg} / \mathrm{kg}$ dose also showed a significant reduction in the tumour weight, as compared to the control. These observations confirmed that KET exerts a significant anticancer effect.

\section{Discussion}

The high incidence of mortality and morbidity has made gastric cancer a great threat to mankind. The high complexity of the underlying mechanism behind its progression has created selective pressure for the discovery of new agents which can inhibit the growth of GC via numerous pathways [19-24]. Cancer-related pain is a significant challenge for the therapeutic management and it is difficult to control with opioid-based analgesics alone [25, 26]. Ketamine is pharmacologically classified as an anaesthetic exhibiting a significant analgesic property at a low dose via antagonising the NMDA (N-methyl-D-aspartate) receptor $[27,28]$. As a result, it is widely used as an adjuvant to opioid therapy for the treatment of cancer-related pain when the pain becomes opioid-resistant. Ketamine, an anaesthetic, analgesic, or sedative, is widely used for the treatment of cancer pain as well as for numerous cancer subtypes [29, 30]. However, no study has elucidated the protective role of ketamine against gastric cancer; thus, in the present study, we tried to determine whether ketamine has any benefit against GC and to elucidate the potential underlying molecular mechanism [31].
In the present study, KET showed reduction of the viability of tested GC cells, viz., BGC-823, MKN45 and MKN-28. Among the tested GC cells, KET showed the most significant inhibitory activity against SGC-823. Thus, it is imperative to understand the mechanism behind this effect; we have evaluated the effect of KET on the apoptosis of SGC-823 cells. Apoptosis is the well-organized and coordinated process of cell death that happens in physiological and pathological conditions. Accumulating evidence suggests that a defect in apoptotic pathways is involved in a number of diseases, ranging from neuro-degeneration to malignancy [32-34]. In the present study, KET was shown to induce apoptosis of SGC-823 cells in a concentration-dependent manner. It causes induction of early and late apoptotic cells as observed by change in morphological characteristics. The occurrence of metastasis is the chief concern for patients with cancer where the malignant cells migrated from the primary site to secondary organs $[35,36]$. Thus, in the present study KET showed significant inhibition of migration of cells in a concentration-dependent manner, and almost complete inhibition of cells was observed in the $10 \mu \mathrm{g} / \mathrm{ml}$ treated group. Studies suggest that cell cycle division is the vital step in the progression of cancer. Thus, novel inhibitors are able to block the cell cycle cascade in order to prevent the proliferation of cancerous cells [37-40]. Our results indicated that KET causes significant inhibition of the cell cycle at the G2/M phase; thus it prevents cells from entering mitosis when DNA 


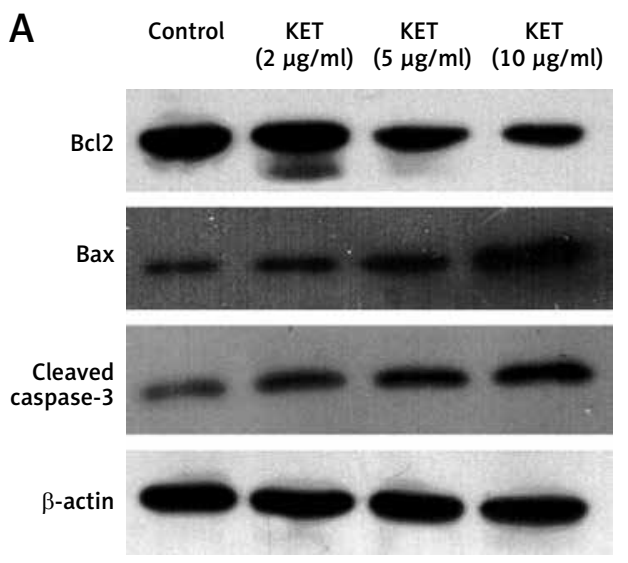

B

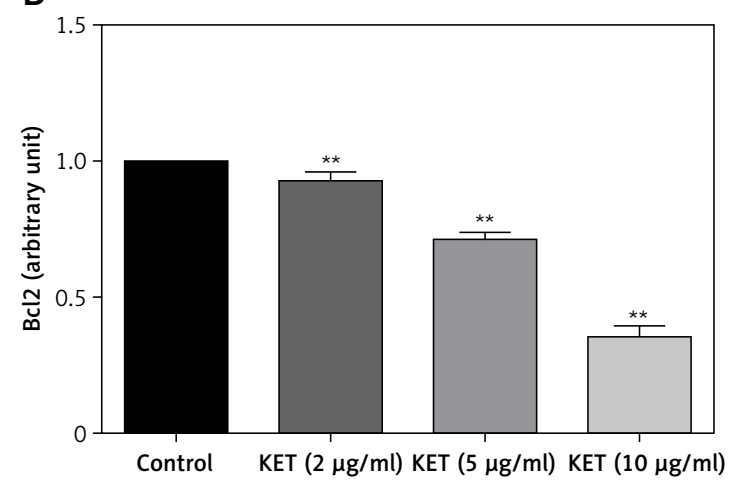

D
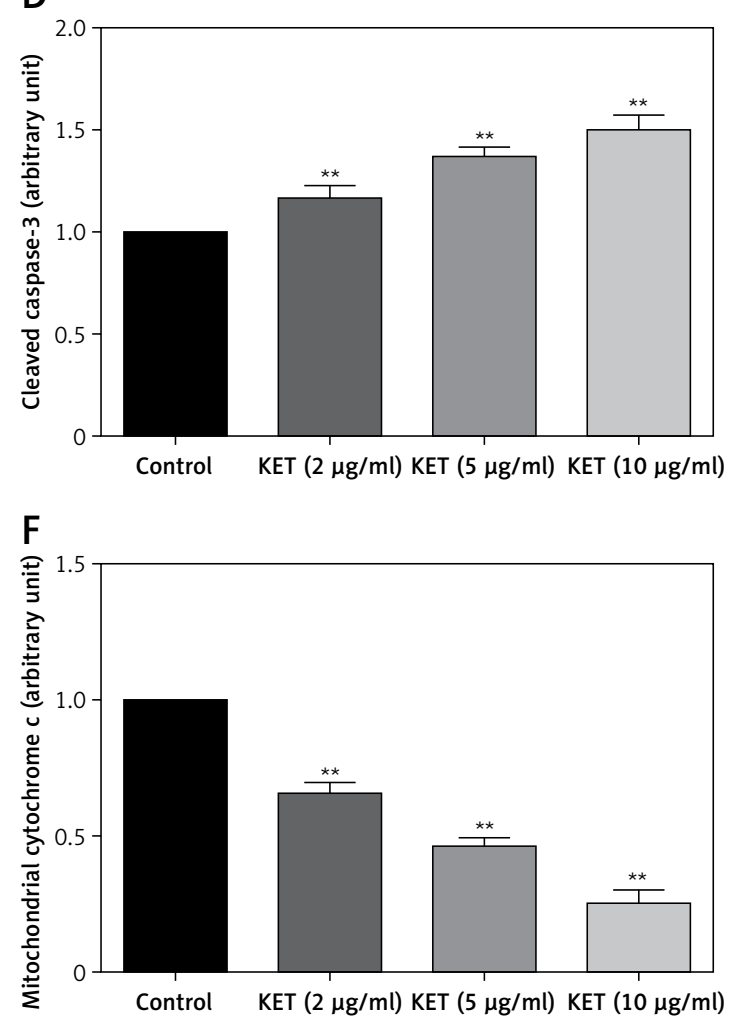

Control KET KET KET $(2 \mu \mathrm{g} / \mathrm{ml}) \quad(5 \mu \mathrm{g} / \mathrm{ml}) \quad(10 \mu \mathrm{g} / \mathrm{ml})$
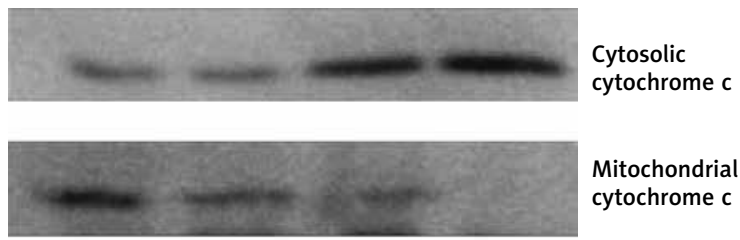

Mitochondrial cytochrome c

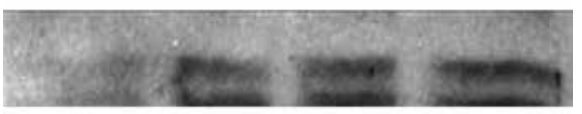

Cytosolic Apaf-1

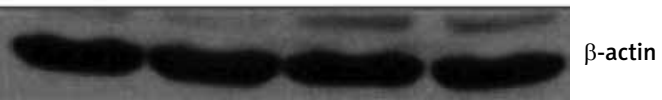

$\mathrm{C}$
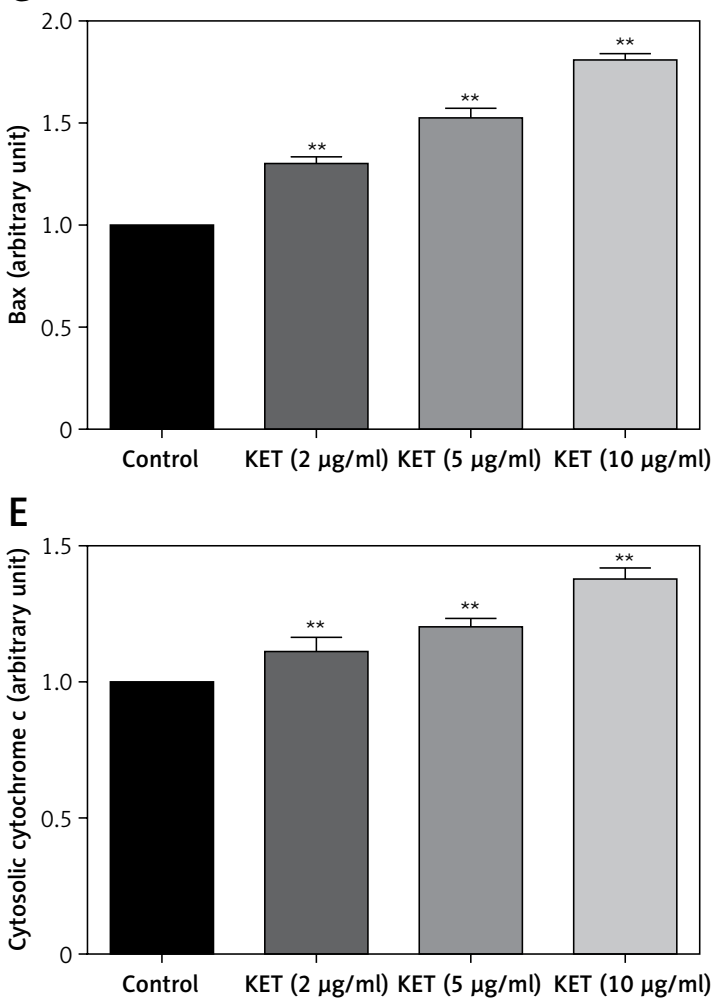

G

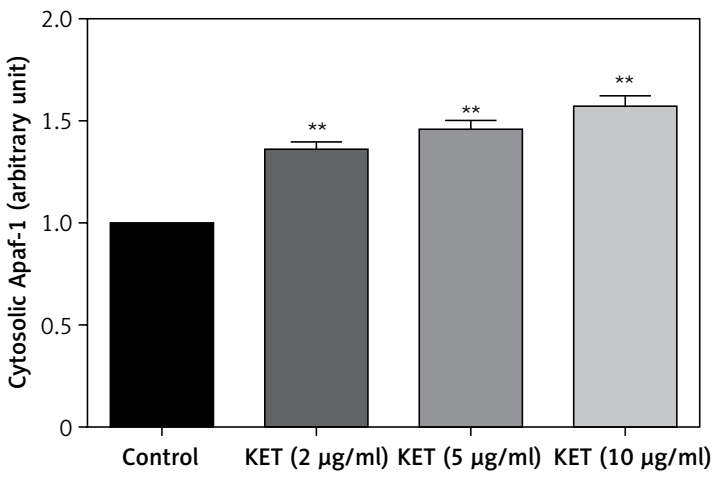

Figure 4. Expression level of apoptosis-related proteins in BGC-823 cells after exposed to KET. A - Western blot analysis of $\mathrm{Bax}, \mathrm{Bcl}-2$, caspase-3, cytosolic cytochrome $\mathrm{c}$, mitochondrial cytochrome $\mathrm{c}$, cytosolic Apaf-1 expressions in BGC-823 cells. Quantitative analysis of Bcl-2 (B), Bax (C), caspase-3 (D), cytosolic cytochrome c (E), mitochondrial cytochrome c (F), cytosolic Apaf-1 (G)

Results represent means $\pm S D$ of three independent experiments. ${ }^{* *} P<0.01 \mathrm{vs}$. control group. 


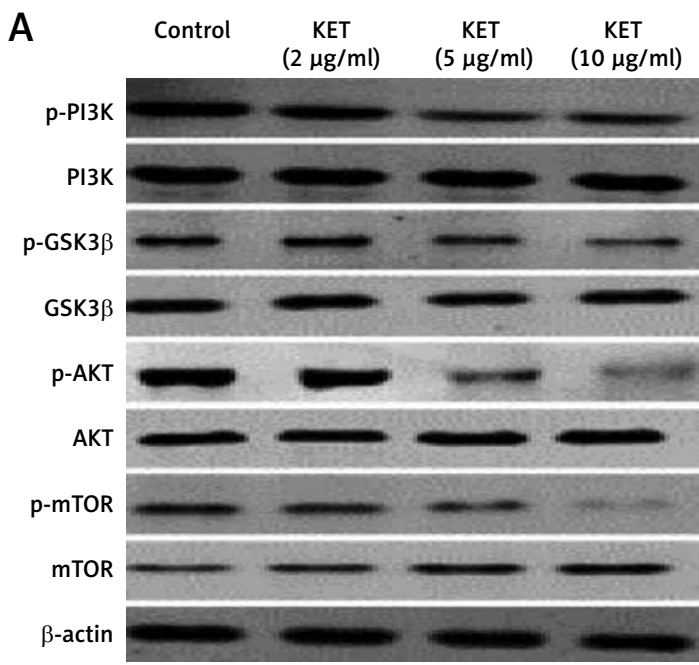

C

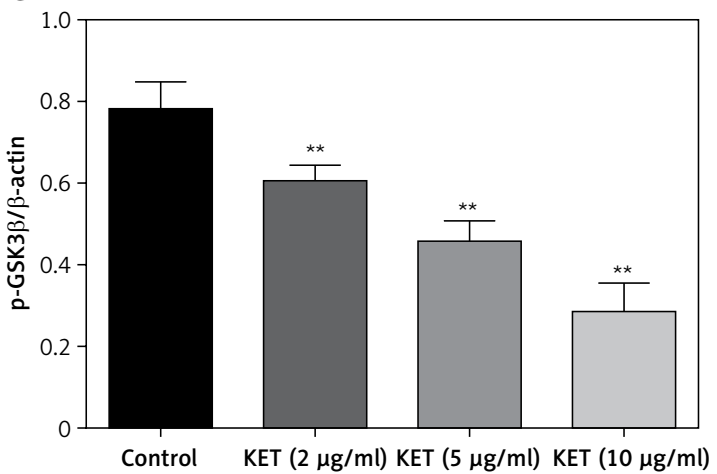

E

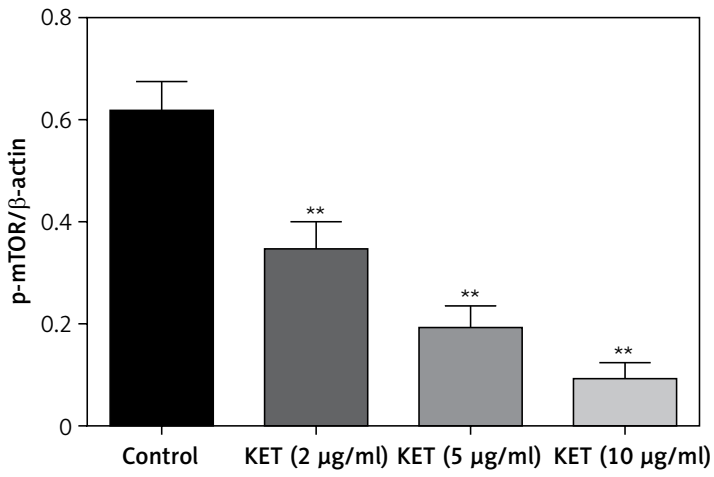

is altered, providing an occasion for restoring and attenuating the propagation of damaged cells. The dysregulation of $\mathrm{Bcl}-2$ family proteins is the characteristic feature of gastric cancer. Thus, classical and recent anticancer agents directly check $\mathrm{BCl} 2$ regulated events at the level of mitochondria [41]. Our results suggest that KET causes the induction of pro-apoptotic proteins such as Bax and reduction of anti-apoptotic proteins such as Bcl-2, as identified by western blot analysis. Studies confirmed that GC has reduced caspase-3 activity and is responsible for the delay in apoptosis [42]. Thus our results indicated that KET cause induction of caspase- 3 activity which might result in
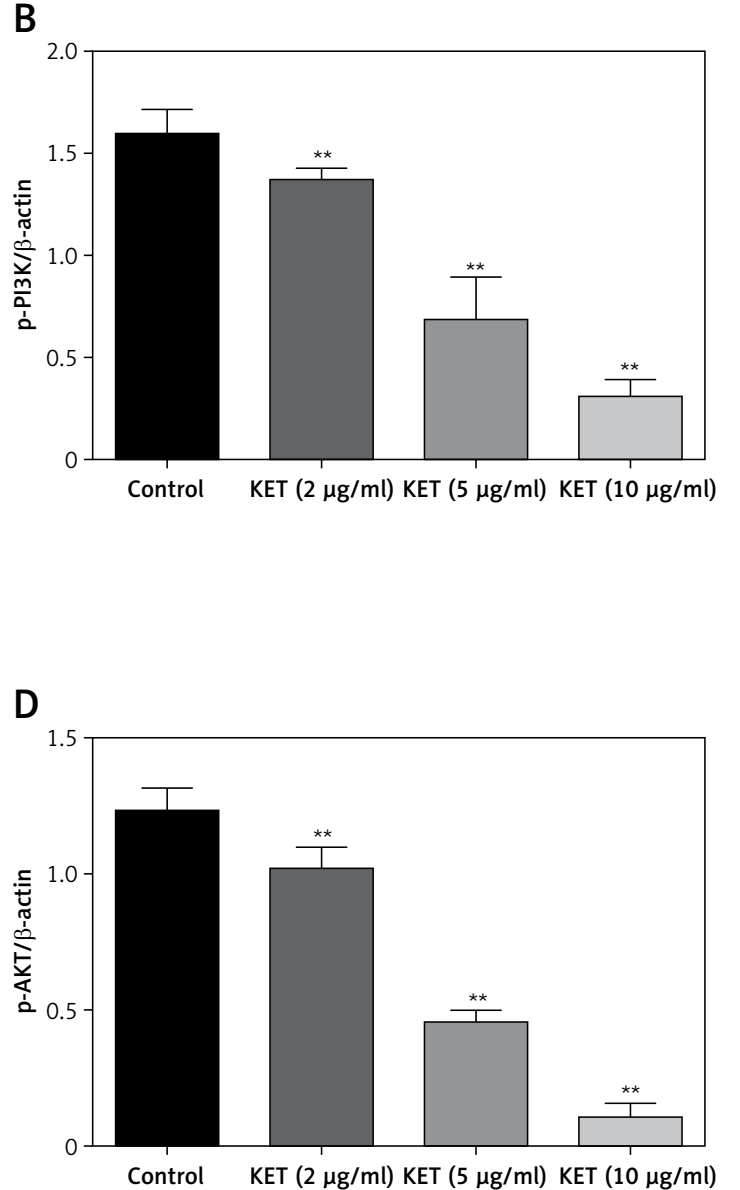

Figure 5. Effect of KET on expression of PI3K/AKT/ TOR pathway proteins. A - Western blot analysis of PI3K, GS3K $\beta$, Akt, mTOR, p-PI3K, p-GS3K $\beta$, p-Akt, and $p$-mTOR. Quantitative analysis of $p$-PI3K (B), p-GSK3ß (C), p-AKT (D), p-mTOR (E)

Results represent means $\pm S D$ of three independent experiments. ${ }^{* *} P<0.01$ vs. control group.

induction of apoptosis for dismantling the cellular structure and its inhibitory activity against gastric cancer. The induction of bax and caspase-3 activity causes loss of mitochondrial membrane potential, causing the release of cytochrome $\mathrm{c}$ from the mitochondria. This released cytochrome $c$ then binds with Apaf- 1 and induces apoptosis [43-45]. Our results suggest that the inhibitory activity of KET against GC possibly occurs by induction of cytosolic cytochrome $\mathrm{c}$ and Apaf-1 together with a decrease in mitochondrial cytochrome $\mathrm{c}$ as evidenced by western blot analysis. These results indicated that KET causes induction of pro-apoptotic proteins vital for inhibition of GC. 
A

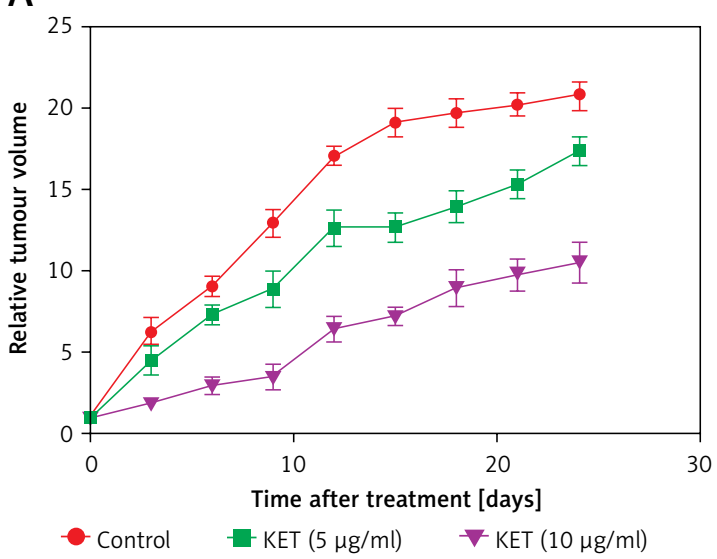

B

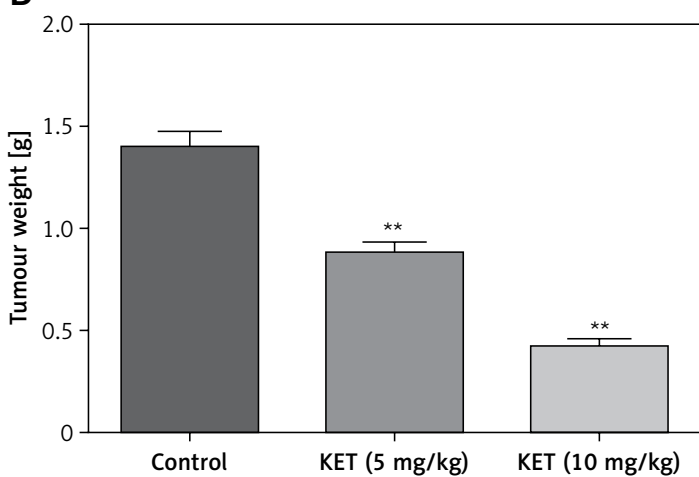

C

Control

KET $(5 \mathrm{mg} / \mathrm{kg})$

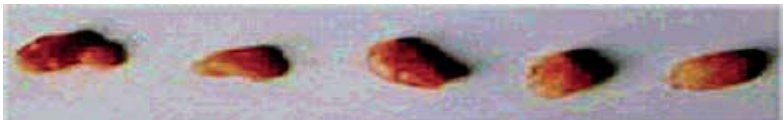

KET $(10 \mathrm{mg} / \mathrm{kg})$

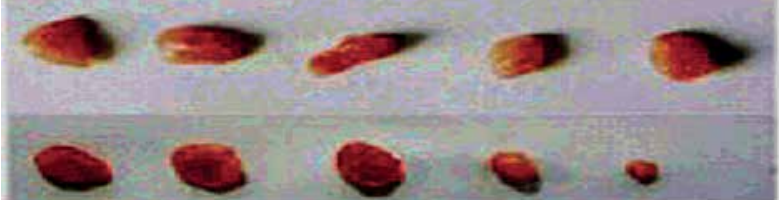

Figure 6. Effect of KET on mouse BGC-823 xenograft model. A - Effect of KET on tumour volume on the indicated day. B - Weight of the tumour at the end of the study. C Tumour image

Results represent means $\pm S D$ of three

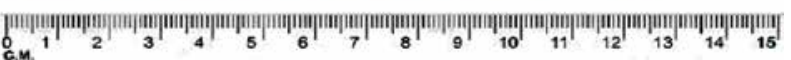
independent experiments. ${ }^{* *} P<0.01$ vs. control group.

Various studies have confirmed the role of $\mathrm{PI} 3 \mathrm{~K} / \mathrm{Akt} / \mathrm{mTOR}$ pathways in the progression of gastric cancer. It causes regulation of numerous cellular events, such as of proliferation, mortality, survival and angiogenesis [46]. This pathway is often found aberrantly activated in gastric cancers [47-49]. Consequently, numerous targeted therapies against this pathway are being tested in clinical trials. Nevertheless, with the exclusion of the ErbB2-targeting antibody, selective agents aiming at $\mathrm{PI3K} / \mathrm{Akt} / \mathrm{mTOR}$ have still not been applied in clinical practice for treatment of gastric carcinoma $[50,51]$. The results of our study indicated that KET causes significant down-regulation of PI3K-AKT-mTOR, which might be recommended as a mechanism for the anticancer effect in gastric cancer. In order to confirm the in vivo activity of KET against GC, we performed the xenograft assay in Balb/c mice [52].

In conclusion, as a concluding remark, the in vitro activity of KET was replicated in an in vivo experiment also. It was found that KET caused significant inhibition of tumour growth as evidenced by the reduction of tumour volume and tumour weight in a mouse SGC-823 xenograft model. Our data emphasize that the anti-gastric cancer activity of ketamine was due to the induction of apoptosis and attenuation of the PI3K/Akt/mTOR pathway. Further investigations focusing on ketamine as a potential agent against gastric cancer are warranted.

\section{Conflict of interest}

The authors declare no conflict of interest.

\section{References}

1. American Cancer Society, Society A, American Cancer Society I. Global Cancer Facts \& Figures $3^{\text {rd }}$ Edition. Am Cancer Soc 2015; doi:10.1002/ijc.27711.

2. National Cancer Institute. Cancer Statistics - National Cancer Institute. NCI. 2016. doi:10.1109/ICMMT.2004.1411457.

3. International Agency for Research on Cancer. World Health Organization. Globocan 2012: Estimated Incidence, Mortality and Prevalence Worldwide in 2012. Cancer 2014; 1-10. doi:10.1002/ijc.27711.

4. Yang L. Incidence and mortality of gastric cancer in China. World J Gastroenterol 2006; 12: 17-20.

5. Singh K, Ghoshal UC. Causal role of Helicobacter pylori infection in gastric cancer: An Asian enigma. World J Gastroenterol 2006; 12: 1346-51.

6. Sugano K. Screening of gastric cancer in Asia. Best Pract Res Clin Gastroenterol 2015; 29: 895-905.

7. Zgodziński W, Grywalska E, Surdacka A, et al. Surface CD200 and CD200R antigens on lymphocytes in advanced gastric cancer: a new potential target for immunotherapy. Arch Med Sci 2018; 14: 1271-80.

8. Wagner AD, Grothe W, Haerting J, Kleber G, Grothey A, Fleig WE. Chemotherapy in advanced gastric cancer: a systematic review and meta-analysis based on aggregate data. J Clin Oncol 2006; 24: 2903-9.

9. Rodon J, Dienstmann R, Serra V, Tabernero J. Development of PI3K inhibitors: lessons learned from early clinical trials. Nat Rev Clin Oncol 2013; 10: 143-53.

10. Hay N. The Akt-mTOR tango and its relevance to cancer. Cancer Cell 2005; 8: 179-83. 
11. Porta C, Paglino C, Mosca A. Targeting PI3K/Akt/mTOR signaling in cancer. Front Oncol 2014; 4: 64.

12. Fruman DA, Rommel C. PI3K and cancer: lessons, challenges and opportunities. Nat Rev Drug Discov 2014; 13: $140-56$

13. Nadjat-Haiem C. Ketamine. In: The Essence of Analgesia and Analgesics. Sinatra RS, Jahr JS, Watkins-Pitchford JM. Cambridge University Press 2010; 316-9.

14. Morgan CJA, Curran HV. Ketamine use: a review. Addiction 2012; 107: 27-38.

15. Malsy M, Gebhardt K, Gruber M, Wiese C, Graf B, Bundscherer A. Effects of ketamine, s-ketamine, and MK 801 on proliferation, apoptosis, and necrosis in pancreatic cancer cells. BMC Anesthesiol 2015; 15: 111.

16. Zhou X, Zhang P, Luo W, et al. Ketamine induces apoptosis in lung adenocarcinoma cells by regulating the expression of CD69. Cancer Med 2018; 7: 788-95.

17. Braun S, Gaza N, Werdehausen R, et al. Ketamine induces apoptosis via the mitochondrial pathway in human lymphocytes and neuronal cells. Br J Anaesth 2010; 105: 347-54.

18. Mohamed EA, Kassem HH. Protective effect of nebivolol on doxorubicin-induced cardiotoxicity in rats. Arch Med Sci 2018; 14: 1450-8.

19. Allum WH, Blazeby JM, Griffin SM, Cunningham D, Jankowski JA, Wong R. Guidelines for the management of oesophageal and gastric cancer. Gut 2011; 60: 1449-72.

20. Gravalos C, Jimeno A. HER2 in gastric cancer: a new prognostic factor and a novel therapeutic target. Ann Oncol 2008; 19: 1523-9.

21. Carneiro F. Hereditary gastric cancer. Pathologe 2012; 33 Suppl 2: 231-4.

22. Correa P, Piazuelo MB, Wilson KT. Pathology of gastric intestinal metaplasia: clinical implications. Am J Gastroenterol 2010; 105: 493-8.

23. Dicken BJ, Bigam DL, Cass C, Mackey JR, Joy AA, Hamilton SM. Gastric adenocarcinoma: review and considerations for future directions. Ann Surg 2005; 241: 27-3.

24. Oliveira C, Pinheiro H, Figueiredo J, Seruca R, Carneiro F. Familial gastric cancer: genetic susceptibility, pathology, and implications for management. Lancet Oncol 2015; 16: e60-70.

25. Tasker Gundy J, Rickerson EM. Cancer pain. In: Essential Clinical Anesthesia Review: Keywords, Questions and Answers for the Boards. Aglio LS, Lekowski RW, Urman RD (eds.). Cambridge 2015; 469-71.

26. Smith TJ, Saiki CB. Cancer pain management. Mayo Clin Proc 2015; 90: 1428-39.

27. Berman RM, Cappiello A, Anand A, et al. Antidepressant effects of ketamine in depressed patients. Biol Psychiatry 2000; 47: 351-4.

28. Autry AE, Adachi M, Nosyreva E, et al. NMDA receptor blockade at rest triggers rapid behavioural antidepressant responses. Nature 2011; 475: 91-5.

29. Bell RF, Eccleston C, Kalso EA. Ketamine as an adjuvant to opioids for cancer pain. Cochrane Database Syst Rev 2017; 6: CD003351.

30. Bell RF. Ketamine for chronic non-cancer pain. Pain 2009; 141: 210-4.

31. Yang $M$, Zhang L, Wang $X$, Zhou Y, Wu S. Down-regulation of miR-203a by IncRNA PVT1 in multiple myeloma promotes cell proliferation. Arch Med Sci 2018; 14: 1333-9.

32. Elmore S. Apoptosis: a review of programmed cell death. Toxicol Pathol 2007; 35: 495-516.

33. Favaloro B, Allocati N, Graziano V, Di Ilio C, De Laurenzi V. Role of apoptosis in disease. Aging (Albany NY) 2012; 4: 330-49.
34. Distelhorst CW. Apoptosis. In: Calcium Signaling. $2^{\text {nd }}$ edn. Putney Jr. JW (ed.). CRC Press 2005; 433-54.

35. Gupta GP, Massagué J. Cancer metastasis: building a framework. Cell 2006; 127: 679-95.

36. Steeg PS. Targeting metastasis. Nat Rev Cancer 2016; 16: 201-18.

37. DiPaola RS. To arrest or not to G2-M cell-cycle arrest. Clin Cancer Res 2002; 8: 3311-4.

38. Figel S, Fenstermaker RA. Cell-cycle regulation. In: Handbook of Brain Tumor Chemotherapy, Molecular Therapeutics, and Immunotherapy. $2^{\text {nd }}$ edn. Newton $\mathrm{H}$ (ed.). Academic Press 2018; 257-69.

39. Yang N, Sheridan AM. Cell cycle. In: Encyclopedia of Toxicology. $3^{\text {rd }}$ edn. Wexler P (ed.). Elsevier 2014; 753-8.

40. Foster I. Cancer: a cell cycle defect. Radiography 2008; 14: 144-9.

41. Korbakis D, Scorilas A. Quantitative expression analysis of the apoptosis-related genes BCL2, BAX and BCL2L12 in gastric adenocarcinoma cells following treatment with the anticancer drugs cisplatin, etoposide and taxol. Tumor Biol 2012; 33: 865-75.

42. Lei $X$, Lv X, Liu M, et al. Thymoquinone inhibits growth and augments 5 -fluorouracil-induced apoptosis in gastric cancer cells both in vitro and in vivo. Biochem Biophys Res Commun 2012; 417: 864-8.

43. Li P, Nijhawan D, Budihardjo I, et al. Cytochrome $\mathrm{c}$ and dATP-dependent formation of Apaf-1/caspase-9 complex initiates an apoptotic protease cascade. Cell 1997; 91: 479-89.

44. Porter AG, Jänicke RU. Emerging roles of caspase-3 in apoptosis. Cell Death Differ 1999; 6: 99-104.

45. Jiang X, Wang X. Cytochrome C-mediated apoptosis. Annu Rev Biochem 2004; 73: 87-106.

46. Pandurangan AK, Ismail S, Esa NM, Munusamy MA. Inositol-6 phosphate inhibits the mTOR pathway and induces autophagy-mediated death in HT-29 colon cancer cells. Arch Med Sci 2018; 14: 1281-8.

47. Riquelme I, Tapia O, Espinoza JA, et al. The gene expression status of the PI3K/AKT/mTOR pathway in gastric cancer tissues and cell lines. Pathol Oncol Res 2016; 22: 797-805.

48. Chen G, Chen SM, Wang X, Ding XF, Ding J, Meng LH. Inhibition of chemokine (CXC motif) ligand 12/chemokine (CXC motif) receptor 4 axis (CXCL12/CXCR4)-mediated cell migration by targeting mammalian target of rapamycin (mTOR) pathway in human gastric carcinoma cells. J Biol Chem 2012; 287: 12132-41.

49. Tapia O, Riquelme I, Leal P, et al. The PI3K/AKT/mTOR pathway is activated in gastric cancer with potential prognostic and predictive significance. Virchows Arch 2014; 465: 25-33.

50. Serra V, Scaltriti M, Prudkin L, et al. PI3K inhibition results in enhanced HER signaling and acquired ERK dependency in HER2-overexpressing breast cancer. Oncogene 2011; 30: 2547-57.

51. Marty B, Maire V, Gravier E, et al. Frequent PTEN genomic alterations and activated phosphatidylinositol 3-kinase pathway in basal-like breast cancer cells. Breast Cancer Res 2008; 10: R101.

52. Fujimoto-Ouchi K, Sekiguchi F, Yasuno H, Moriya Y, Mori K, Tanaka Y. Antitumor activity of trastuzumab in combination with chemotherapy in human gastric cancer xenograft models. Cancer Chemother Pharmacol 2007; 59: 795-805. 